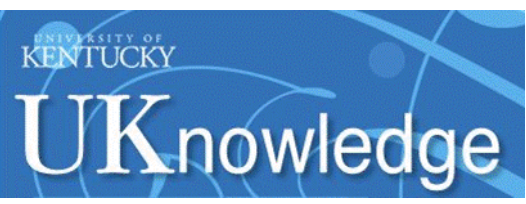

Kentucky Law Journal

\title{
Should Paris Hilton Receive a Lighter Prison Sentence Because She's Rich? An Experimental Study
}

Josef Montag

Mendel University

Tomáš Sobek

Masaryk University and the Institute of State and Law, the Academy Sciences of the Czech Republic

Follow this and additional works at: https://uknowledge.uky.edu/klj

Part of the Criminal Law Commons, and the Law and Society Commons

Right click to open a feedback form in a new tab to let us know how this document benefits you.

\section{Recommended Citation}

Montag, Josef and Sobek, Tomáš (2015) "Should Paris Hilton Receive a Lighter Prison Sentence Because She's Rich? An Experimental Study," Kentucky Law Journal: Vol. 103: Iss. 1, Article 6.

Available at: https://uknowledge.uky.edu/klj/vol103/iss1/6 


\title{
Should Paris Hilton Receive a Lighter Prison Sentence Because She's Rich? An Experimental Study
}

\author{
Josef Montag and Tomáš Sobek ${ }^{2}$
}

The 'equal punishment for the same crime' principle is generally agreed upon-yet its implementation differs radically depending on whether the punishment is measured purely in nominal terms or whether the subjective perspective of the punishee is accounted for. This is simply because different people may experience the same punishment with differing intensity.

Legal scholars have recently proposed that improvements in scientific knowledge and advancements in technologies (such as Functional magnetic resonance imaging), which allow us to measure subjective perceptions and feelings, need to be and should be incorporated in our penal systems. This would facilitate calibrating the punishment not only to the crime but also to the offender's persona, so that different people experience equally tough punishment for the same crime.

However, such a substantial change in criminal law and policy necessitates a certain amount of public legitimacy and understanding among constituents. We ran a simple experiment in order to learn how people understand punishment and to ascertain whether such legitimacy exists.

\footnotetext{
I Corresponding author. Faculty of Business and Economics, Mendel University. Address: Zemědělská 1, 61300 Brno, Czech Republic. Email: josef.montag@mendelu.cz.

${ }^{2}$ Faculty of Law, Masaryk University and the Institute of State and Law, the Academy of Sciences of the Czech Republic.
}

\begin{abstract}
We have received valuable comments and criticisms from the following individuals: Jan Broulik, Libor Dušek, Petr Houdek, Peter Huber, Lucca Pieroni, and Vladimir Kozlov. We also received helpful input from participants at the 2013 meeting of the European Association of Law and Economics at the University of Warsaw, the 2013 meeting of the German Law and Economics Association at the Free University of Bolzano, and the seminar participants at Tilburg Law School. Any remaining mistakes and imperfections are our responsibility and we hope that any associated punishments will be determined so as to take into account our diverging personalities and individual sensitivities. Lastly, we would like to thank Peter Bolcha, Marek Hudík, and Martina Urbanová for providing access to student respondents.
\end{abstract}

This work was supported by the "Program of Employment of Best Young Scientists for International Cooperation Empowerment" (CZ.1.07/2.3.00/30.0009) and co-financed from "European Social Fund" and the state budget of the Czech Republic. 
We find such a legitimacy may exist in the case of pecuniary punishments. With regard to incarceration policies, however, the likelihood of popular acceptance of proposed innovations is rather remote. Our findings therefore point out a serious challenge for the scholarship favoring the subjective approach to punishment and may complicate the implementation of suggested reforms, even if legal scholars find them worthwhile.

\section{INTRODUCTION}

Paris Hilton was sentenced to serve a term of 45 days in a county jail for violating her probation, halting the hotel heiress's famous high life. She was originally sentenced for reckless driving involving alcohol. The judge's ruling excluded her from paying to serve time in a jail of her choice. Hilton, due to claustrophobia or the fact that she was accustomed to living in luxurious surroundings, may have experienced confinement in a much more frightened and tormented way than the average person would. One of her attorneys, Howard Weitzman, stated explicitly that the sentence was "uncalled for, inappropriate and bordered on the ludicrous." 3

\section{A. The Debate: Objective versus Subjective Punishment}

Punishment is the coercive imposition of something undesirable or unpleasant upon an individual, or else it does not punish. ${ }^{4}$ From a historical point of view, punitive practices include fines, incarceration, disgrace, forced labor, bodily suffering, and death. "Perhaps the most obvious quality that these practices have in common is that they are all in some way bad for the person on whom they are inflicted." The "bad" associated with a punishment can be understood objectively (e.g., a deprivation of certain amount property or liberty) or subjectively as the amount of psychological distress created by it. At the same time, a particular punishment will rarely produce the same degree of discomfort in two different persons. ${ }^{6}$ Its actual effect on a person's wellbeing depends on her constitution and other personal circumstances.

For instance, the discomfort associated with a $\$ 200$ fine will be a decreasing function of the offender's income (provided her marginal utility of money is

\footnotetext{
${ }^{3}$ Sandy Cohen, Paris Hilton Going to Jail for 45 Days, WASH. POST (May 4, 2007, 10:26 PM), http://www.washingtonpost.com/wp-dyn/content/article/2007/05/04/AR2007050400489.html.

4 See H. L. A. HART, Punishment AND RESPONSIBILITY: ESSAYS IN THE PHILOSOPHY OF LAW 4-6 (1968).

${ }^{5}$ DAVID BoONIN, THE PROBlem OF PUNISHMENT 6 (2008).

6 See 2 JeREMy Bentham, AN INTRODUCtion to THE PRINCIPLES OF MORALS AND Legislation 21-22 (London, W. Pickering 1823); see also Richard A. Posner, An Economic Theory of the Criminal Law, 85 COLUM, L. REV. 1193, 1212 (1985) ("The economic objection to punishing by inflicting physical pain is not ... that people have different thresholds of pain that make it difficult to calibrate the severity of the punishment-imprisonment and death are subject to the same problem. ${ }^{\prime}$ ).
} 
decreasing). Intuitively, such a fine will have a substantial effect on the next month's plans for a person with monthly earnings of $\$ 1,500$; whereas it would have barely any for someone earning $\$ 15,000$. Similar variation can be expected in prison experiences. For instance, a homeless person sentenced to spend eight weeks in a county jail for petty larceny may feel very different depending on whether she is to present herself in January or in May. A person suffering from claustrophobia will have greater difficulty coping with incarceration than a person without such a condition. Another factor influencing the shock and pain related to incarceration is income. This is because the punishee's starting conditions, her opportunities forgone, any fall in social hierarchy, and so on, also depend on income. ${ }^{7}$ Thus, while the "equal punishment for the same crime" principle is generally agreed upon, its implementation differs radically depending on whether the equality is understood in substantive or purely formal terms.

According to the subjectivist view, punishment is a legitimate means to produce subjective disutility. Or, put bluntly, the subjective disutility is the punishment. Therefore, we should measure a punishment's severity based on the subjective experiences of each individual punishee. Thus, the equality of punishment, in the subjectivist conception, requires sameness in the impact of punishment on punishees as sentient beings. As a result, two people who committed the same crime under similar circumstances should often receive different punishments if their subjective experience of a given punishment would be different. ${ }^{8}$

The law accommodates the subjective aspects of punishment in some cases. Juveniles are treated differently from adults, and first time offenders normally receive a lighter punishment than recidivists. ${ }^{9}$ The sentencing mitigation takes into

${ }^{7}$ See Gary S. Becker, Crime and Punishment: An Economic Approach, 76 J. POL. ECON. 169, 195 (1968) ("Indeed, if the monetary value of the punishment by, say, imprisonment were independent of income, the length of the sentence would be inversely related to income, because the value placed on a given sentence is positively related to income."); see also Adam J. Kolber, Essay, The Subjective Experience of Punishment, 109 COLUM. L. REV. 182, 230 (2009) [hereinafter The Subjective Experience] (" $[\mathrm{A}] \mathrm{s}$ an empirical matter, wealthy people are likely to suffer more intensely in prison than those with less wealth who are placed in the same prison conditions."). See generally A. Mitchell Polinsky \& Steven Shavell, The Optimal Use of Fines and Imprisonment, 24 J. PUB. ECON. 89, 89-90 (1984) ("When fines are used alone and individuals are identical, the optimal fine equals their wealth.").

${ }^{8}$ See Kolber supra note 7 , at 182 . There is a parallel controversy about the 'equal punishment for the same crime' principle. The pay-to-stay programs provide an alternative to serving time in a county jail following a criminal conviction. Nonviolent offenders can pay for better accommodations, a clean, quiet cell, separated from other, nonpaying, prisoners. Some people perceive this to be unfair and unequal justice: two persons committed the same offense, but the rich person has the option to be in a better cell while the poor does not. See generally Laurie L. Levenson \& Mary Gordon, The Dirty Little Secrets about Pay-to-Stay, $106 \mathrm{MICH}$. L. REV. FIRST IMPRESSIONS 67, 69-70 (2007), $\mathrm{http}: / /$ www.michiganlawreview.org/assets/fi/106/levensongordon.pdf (advocating for an open discussion to resolve the inequalities resulting from the private sector's involvement with correctional facilities).

${ }^{9}$ Most, if not all, legal systems are designed to punish repeat offenders more severely than first time offenders, and this principle of escalating sanctions is reflected in many penal codes and sentencing guidelines. Notably, however, from the optimal deterrence point of view, repeat offenders are likely to face higher probabilities of detection than will offenders with clean records. See David A. Dana, Rethinking the Puzzle of Escalating Penalties for Repeat Offenders, 110 YALE L.J. 733, 735 (2001) 
consideration some personal factors, including the degree of offender's sensitivity to a harsh punishment due to advanced age, illness, or disability. ${ }^{10}$ In addition, criminal codes of some countries explicitly allow differentiation in punishment due to the income or financial circumstances of the offenders. This, however, applies almost exclusively to monetary punishments. ${ }^{11}$

Thus, we can still ask whether the penal system is sufficiently perceptive to the subtle factors that create variation in the subjective experience of punishment. The lack of such sensitivity may exist because ascertaining and weighing such factors was prohibitively costly hitherto. ${ }^{12}$ Recent advancements in psychology, neuroscience, and technology, such as functional magnetic resonance imaging (fMRI), however, have improved our ability to understand, objectively measure, and predict people's subjective experience of punishment and its discomfort. ${ }^{13} \mathrm{~A}$

("Indeed, the general principle of escalating penalties based on offense history is so widely accepted that it strikes most people as simple common sense."); Winand Emons, Escalating Penalties for Repeat Offenders, 27 INT'L REV. L. \& ECON. 170, 171, 176-77 (2007); Tim Friehe, Escalating Penalties for Repeat Offenders: A Note on the Role of Information, 97 J. ECON. 165, 165 (2009); Thomas J. Miceli \& Catherine Bucci, A Simple Theory of Increasing Penalties for Repeat Offenders, 1 REV. L. \& ECON. 71, 71 (2005); Murat C. Mungan, Repeat Offenders: If They Learn, We Punish Them More Severely, 30 INT'L REV. L. \& ECON 173, 173 (2010); A. Mitchell Polinsky \& Daniel L. Rubinfeld, A Model of Optimal Fines for Repeat Offenders, 46 J. PUB. ECON. 291, 291-93 (1991); A. Mitchell Polinsky \& Steven Shavell, On Offense History and the Theory of Deterrence, 18 INT'L REV. L. \& ECON. 305, 305-06 (1998).

${ }^{10}$ See Austin Lovegrove, Proportionality Theory, Personal Mitigation, and the People's Sense of Justice, 69 CAMBRIDGE L.J. 321, 323 (2010).

${ }^{11}$ Compare Zákon č. 40/2009 Sb. §39 (1) (Czech Republic), with BUNDEsGESETZ [FEdERAL STATUTE] (BG) BUNDESGESETZBLATT [BGBL] No. 60/1974, §19(2) (Austria), and Bulgarian CC, Art. 47 (1968); CODE PÉNAL [C. PÉN.] art. 132-24 (Fr.), and STRAFGESETZBUCH [STGB] [PENAL CODE], Nov. 13, 1998, BUNDESGETzBLATT TEIL [BGBL. II] 3322, as amended, §46(2) (Ger.), and UGOLOVNYI KODEKS ROSSIIKOI FEDERATSII [UK RF] [Criminal Code] art. 46 (Russ.), and Serbian CC, Art. 54 (2) (2005); and SCHWEIZERISCHES STRAFGESTZBUCH [STGB] [CRIMINAL CODE] Dec. 21, 1937, SR 757 (1938), art. 34(2) (Switz.). In this context, 1974 évi IV. Törvény a Büntetô Törvénykönyvröl (Act IV of 1974 on the Criminal Code) (Hung.), is a very interesting provision:

(1) The person who is sentenced to imprisonment of a definite duration and has appropriate earnings (income) or property a) shall be sentenced to fine as a supplementary punishment, if he perpetrates the crime for profit-making, b) may be sentenced to fine as supplementary punishment, if he can be more efficiently restrained thereby from the perpetration of a new crime.

${ }^{12}$ See Posner, supra note 6, at 1212.

\begin{abstract}
The infliction of physical pain is not the only way in which the severity of punishment can be varied other than by varying the length of imprisonment. Size of prison cell, temperature, and quality of food could also be used as 'amenity variables.'. . The problem is that this would make information about sanctions very costly, because there would be so many dimensions to evaluate. Time has the attractive characteristic of being one-dimensional, and differs from pain in that it has more variability.
\end{abstract}

Id.

${ }^{13}$ See K. Fliessbach et al., Social Comparison Affects Reward-Related Brain Activity in the Human Ventral Striatum, 318 SCIENCE 1305, 1306, 1308 (2007); Andrew J. Oswald \& Stephen Wu, Objective Confirmation of Subjective Measures of Human Well-Being: Evidence from the U.S.A., 327 SCIENCE 
group of legal scholars, known as the 'subjectivists', have recently been arguing that such improvements in scientific knowledge and technology should be incorporated into criminal law, in order to ensure that punishment generates a uniform and appropriate amount of suffering for the offender, for a given crime. ${ }^{14}$ Indeed, it may one day be possible to tailor punishment to each individual's circumstances and thereby heal the gross inequalities in the effects of penalties on offenders' subjective wellbeing. Only then, according to the subjectivists, will offenders of the same crime receive an equal punishment. ${ }^{15}$

On the other hand, the objectivist conception demands that punishment be nominally equal (for instance, the same number of months in prison or a fine of the same amount of dollars). They postulate that the purpose of punishment is not to produce a certain amount of suffering in the offender but for the offender to pay just deserts for her misdoings. The objectivists deem the subjective experience of a punishee as utterly irrelevant and, as a result, abstract away from the subjective effects of punishment. They demand that punishment should remain objective, limiting our attention to acts, culpability, and desert. ${ }^{16}$ The variation in how the

576, 576-79 (2010); Enrico Schulz et al., Decoding an Individual's Sensitivity to Pain from the Multivariate Analysis of EEG Data, 22 CEREBRAL CORTEX 1118, 1118 (2012); Alexander Weiss et al., Evidence for a Midlife Crisis in Great Apes Consistent with the U-shape in Human Well-Being, 109 Proc. NAT. ACAD. SCI. 19,949, 19,949 (2012). But see Greg Miller, Brain Scans of Pain Raise Questions for the Law, 323 SCIENCE 195, 195 (2009) (suggesting that fMRIs may be uncertain and possibly unreliable, but insisting that they will likely find their place inside a courtroom).

${ }^{14}$ See John Bronsteen, Christopher Buccafusco \& Jonathan Masur, Happiness and Punishment, 76 U. CHI. L. REV. 1037, 1037-1039 (2009); John Bronsteen, Christopher Buccafusco \& Jonathan Masur, Retribution and the Experience of Punishment, 98 CALIF. L. REV. 1463, 1463-1465 (2010); Adam J. Kolber, Against Proportional Punishment, 66 VAND. L. REV. 1141, 1155-70 (2013) [hereinafter Proportional]; Adam J. Kolber, The Comparative Nature of Punishment, 89 B.U. L. REV. 1565, 156668 (2009) [hereinafter Comparative]; Adam J. Kolber, The Experiential Future of the Law, 60 EMORY L.J. 585, 585, 587 (2011); The Subjective Experience, supra note 7, at 182; Adam J. Kolber, Unintentional Punishment, 18 LEGAL THEORY 1, 2 (2012). For sociological and economic research along these lines see John R. Lott, Jr., Do We Punish High Income Criminals Too Heavily?, 30 Econ. INQUIRY 583, 584 (1992) for an examination of the reduction in earnings due to conviction; also see Michael Massoglia, Incarceration as Exposure: The Prison, Infectious Disease, and Other StressRelated Illnesses, 49 J. HEALTH \& SOC. BEHAV. 56 (2008) for a discussion on the health consequences of inmates after prison, and see Devah Pager, The Mark of a Criminal Record, 108 AM. J. SoC. 937, 937 (2003) for a dialogue on the consequences of incarceration for the employment outcomes of black and white job seekers.

${ }^{15}$ See generally The Subjective Experience, supra note 5, at 183-98, 235 (arguing that "any successful justification of punishment must take subjective experience into account"). Note that an analogous discussion exists in the literature on civil damages. For instance, the outrage model is a subjective approach to punitive damages. It considers damages an expression of an angry attitude toward a transgressor. See Daniel Kahneman, David Schkade \& Cass R. Sunstein, Shared Outrage and Erratic Awards: The Psychology of Punitive Damages, 16 J. RISK \& UNCERTAINTY 49, 64 (1998) ("In the outrage model, punitive intent is an intention to inflict pain; this means that the size of the defendant matters a good deal."). See generally Theodore Eisenberg et al., Juries, Judges, and Punitive Damages: An Empirical Study, 87 CORNELL L. REv. 743, 751, 758 (2002) (addressing the relationship between punitive and compensatory damages awarded in both judge and jury trials).

${ }^{16}$ See David Gray, Punishment as Suffering, 63 VAND. L. REV. 1619, 1624 (2010); Dan Markel \& Chad Flanders, Bentham on Stilts: The Bare Relevance of Subjectivity to Retributive Justice, 98 CALIF. L. REV. 907, 909 (2010) [hereinafter Bentham]. See generally Dan Markel, Chad Flanders \& David 
offender actually experiences the punishment is external to the punishment itself and therefore does not enter into the determination of the size of that punishment. An objectivist can also point out to the significant measurement and quantification problems still associated with a subjective punishment conception. He will claim that this uncertainty is inconsistent with non-arbitrariness and predictability as elements of the Due Process Clause. ${ }^{17}$

\section{B. This Study}

Both sides of the debate have substantial merit and producing nontrivial arguments. ${ }^{18}$ Although minorities of scholars take the subjectivist approach, its

Gray, Beyond Experience: Getting Retributive Justice Right, 99 CALIF. L. REV. 605, 605-606 (2011) (discussing whether punishment should be viewed from the subjective standpoint of the prisoner or viewed from the broad, objective standpoint of the law).

${ }^{17}$ See LARRY MAY, GLOBAL JUSTICE AND DUE PROCESS 107-09 (2010) (discussing the idea of no arbitrary imprisonment or punishment, as a component of the traditional notions of due process of law). See generally E. THOMAS SUllivan \& TONI M. MASSARO, THE ARC OF DUE PROCESS IN AMERICAN CONSTITUTIONAL LAW 216-38 (2013) (examining the origins and contmeporary uses of due process principles). Note, however, that a similar criticism can also be levied against the objectivist conception of punishment.

${ }^{18}$ The controversy between subjectivist and objectivist approaches to punishment is, indeed, relevant to the two main theories of criminal punishment, which are consequentialism and retributivism. See generally BOONIN supra note 3 (exploring the problems of punishment, particularly the unequal treatments of a state's citizens and arguing that there is no satisfactory solution to the problem); TED HONDERICH, PUNISHMENT: THE SUPPOSED JUSTIFICATIONS REVISITED (rev. ed. 2006) (discussing the problems with punishment and its various theories); NICOLA LACEY, STATE PUNISHMENT: POLITICAL PRINCIPLES AND COMMUNITY VALUES (Ted Honderich ed., 1988) (explaining that there is no adequate justification for punishment while discussing the theories within a political and philosophical framework); MATT Matravers, Justice and PUNISHMEnT: The Rationale of COERCION (2000) (answering a question posed by Tolsty which asks, "why, and by what right do some people punish others?"); MICHAEL MOORE, PLACING BLAME: A THEORY OF THE CRIMINAL LAW (1997) (discussing retributivism). The consequentialist justifications of punishment lie in the idea that punishment is only justifiable on the basis of its good consequences. See Posner supra note 6, at 1207 (" $[R]$ educing the penalty for a lesser crime may reduce the incidence of a greater crime. If it were not for considerations of marginal deterrence, more serious crimes might not always be punishable by more severe penalties than less serious ones."). Thus, it seems the consequentialists are in the end committed to subjectivism, as tailoring punishments to criminals' personae may yield more precise deterrence incentives and, as a consequence, a more efficient use of public resources. See id. at 1212 ("It may seem very attractive from a cost-effectiveness standpoint to reduce the length of imprisonment but compensate by reducing the quality of the food served the prisoners; the costs of imprisonment to the state, but not to the prisoners, would be reduced."). See generally Becker, supra note 7, at 209 (advocating for an "economic framework for illegal behavior"); Polinsky \& Shavell, supra note 7, at 8990 (discussing the use of both fines and imprisonment to deter illegal behavior). The retributivist theories by and large present the opinion that punishment is justified only when a punished person deserves it and offenders should face a punishment that is in proportion to their blameworthiness. See 16 JESPER RYBERG, THE ETHICS OF PROPORTIONATE PUNISHMENT: A CRITICAL INVESTIGATION 15-17 (2004). See generally Herbert Fingarette, Punishment and Suffering, 50 PROC. \& ADDREsSES AM. PHIL. ASS'N 499, 499 (1977). Therefore, retributivists need to disambiguate the notion of the severity of punishment and, as a consequence, they face the dilemma of whether punishment is to be determined according to the subjectivist or the objectivist conception. See Gray, supra note 16, at 167071; Comparative, supra note 14, at 1569; Proportional, supra note 14, at 1161 ; Bentham, supra note 14, 
relevance may grow with new scientific knowledge and technology. The recent debate may well be a reflection of that. Thus, given the size of the stakes and farreaching implications for public policy, the literature needs to take into consideration how people understand the role of criminal punishment and its legitimacy. This Article aims to contribute to the debate by investigating two closely related research questions: (i) Do people consider subjective perception to be a legitimate determinant of punishment? (ii) Is the answer the same for different types of sanctions? ${ }^{19}$

Learning about people's attitudes towards subjective aspects of punishment is important for three main reasons: (i) It is important that existing penal policies are perceived to be legitimate, especially as possibilities for innovations and enhancements emerge. ${ }^{20}$ (ii) Even scientifically sound policy innovations in the criminal law system need to be accepted by the general public. A better understanding of people's beliefs and attitudes is directly relevant to policy design and framing. Thus, this Article is directly relevant to the current theoretical battle between the subjectivists and the objectivists and provides important empirical information on the feasibility of subjectivist reforms of the criminal law. (iii) People's views and attitudes, apart from giving legitimacy to policies, often are grounded in common sense. While we acknowledge that sound policies may contradict popular opinion, we note that in cases where they do, arguments must be carefully crafted and the policy's legitimacy must be drawn from elsewhere in order to outweigh the common sense solutions. ${ }^{21}$

We have designed and run a survey experiment in order to gain insights into these questions. The experiment focuses on fines and incarceration, as they are the most salient types of punishment, and studies the role of the offender's income as a major source of variation in the subjective perception of punishment. Our main focus is on the relationship between punishment and wealth because it is straightforward enough to link systematic differences in the subjective effects of punishment to wealth ${ }^{22}$ and the related policy implications of the subjectivists' perspective are rather controversial. The design facilitates identification of implicit rules as well as unconscious attitudes towards the two main types of criminal punishment.

The experiment has generated a rich dataset that allows us to gain substantial insight into the phenomena underpinning the study. Briefly, the results suggest that policy changes that would link the value of fines to the offenders' income may be acceptable or even welcome. Indeed, about sixty percent of our subjects

at 911. See generally The Subjective Experience, supra note 5, at 204 (criticizing a purely objective approach to punishment).

${ }^{19}$ See generally Dan M. Kahan, What do Alternative Sanctions Mean?, 63 U. CHI. L. REV. 591, 592 (1996) (analyzing the importance of how punishment is perceived by the public).

${ }^{20}$ See generally id. at 594.

${ }^{21}$ The general approach pursued in this study is analogous to one found in Cass R. Sunstein, David Schkade \& Daniel Kahneman, Do People Want Optimal Deterrence?, 29 J. LEGAL STUD. 237, 237, 239 (2000).

${ }^{22}$ See Becker, supra note 7, at 197; The Subjective Experience, supra note 7, at 235. 
supported varying fines with income. However, almost ninety percent of our subjects thought that wealth should not affect prison sentencing-even if one can reasonably assume that it systematically affects the punishee's subjective experience of their punishment. ${ }^{23}$ Our findings are dramatic as well as robust, and we believe that they identify important challenges for the innovation of criminal law and policies proposed by the subjectivists. ${ }^{24}$

\section{STUDY DESIGN}

The structure of our experimental design is straightforward and is implemented as a survey. Specifically, each subject is asked to assess two criminal cases in which the defendant has been convicted. The cases are presented one at a time so that the facts of the second case are revealed only after the first case is concluded. In each case, we ask our subjects to decide on the punishment, which consists of a fine and a prison term; we only restrict their decisions to non-negative numbers. The two cases only differ in defendant's income and his profession. ${ }^{25}$

We randomize the order of the two cases so that one group of subjects first evaluates the case with the poor defendant and the second group first evaluates the case with the rich defendant. Additionally, in order to ascertain the possibility that our data are an artifact of a particularly chosen criminal scenario, we use two types of scenarios: a car accident and a bar fight. These two scenarios vary across respondents, but not within, so that each respondent deals with only one scenario in all her decisions.

${ }^{23}$ Wealthy people experience imprisonment as a bigger drop in living standards than does the average person.

${ }^{24}$ The data and computer code results are available from the authors upon request.

${ }^{25}$ We varied the profession of the defendant to keep the story realistic. We used "a plumber" and "a programmer" and believe these professions are fairly neutral. Our follow-up discussions with pre-test respondents support this assumption. 


\section{A. The Scenarios ${ }^{26}$}

The car accident scenario involves reckless driving under the influence of alcohol, and the defendant has no prior criminal record. The fight scenario also involves alcohol, but, here, the defendant received a suspended sentence for an alcohol-related accident a few years prior. In both scenarios, the victim suffered injuries that required hospitalization and several months to fully recuperate. Thus, the two scenarios represent two qualitatively different types of crime: an accident due to reckless behavior and a violent attack.

The victim has the right to be compensated for her (or his, in the fight case) material losses and forgone earnings, as well as for his or her pain and suffering. A court expert has established the extent of these damages. ${ }^{27}$ This is important for two reasons: (i) the punishment itself does not need to serve to compensate the victim or seek revenge for her suffering (this does not preclude a punishment motivated by retribution for society); (ii) together with defendant's income, it serves as an implicit budget constraint, so that our subjects are encouraged to think about the criminal's means and his capacity to pay for the damages as well as the fine.

\section{B. Experimental Variation and Its Interpretation}

This experimental design creates two main sources of variation, namely between-group variation and within-subject variation. Between-group comparison gives us an insight into whether people take income into consideration when deciding on a fine or the length of a prison term. However, we are interested in whether this is a part of an implicit rule or an unconscious attitude, tendency, or a bias. This is when the within-subject variation comes in. If the defendant's income is part of the rule, we expect differences between the first and second decisions since they differ only in the defendant's income. Alternatively, if our subjects disregard income as a decision variable, they should give the same solution in both cases. Our design also allows people to decide to take income into consideration for the fine and to disregard it when deciding about the prison sentence, or vice versa. Thus, the identifying assumption of this design is: the decision in the second case in the sequence has to be logical, in other words, the initial decision is a binding precedent.

${ }^{26}$ The instructions and criminal scenarios used in our study are available in the Appendix. See infra Appendix, Part B.

${ }^{27}$ The amount of the damages used in the study represents approximately twenty months of aftertax income for the poor criminal and three months of after-tax income for the rich criminal. See infra text accompanying notes $28-29$. 


\section{Implementation}

We ran our experiment using the SoSci Survey (www.soscisurvey.de) website. ${ }^{28}$ It offers tools for creating, testing, and running surveys. It also facilitates randomization via PHP code. ${ }^{29}$ The respondents are firstly informed that they will participate in a study on people's attitudes toward pecuniary punishment and incarceration and that there will be a sequence of cases they need to evaluate. We told them explicitly that no particular jurisdiction applies so that they may and should choose the punishment they feel is (de lege ferenda) appropriate.

After the initial instructions, subjects are presented with the facts of the first case. The task is to decide on the appropriate mix of a prison term in days and a fine in Czech Crowns. After making their first decision, subjects are presented with the second case. The only differences from the first case are the defendant's income level and his profession: half of the subjects first decide a case with a poor defendant (a plumber who earned a net monthly income of 12,270 and 13,330 Czech Crowns ${ }^{30}(\mathrm{CZK})$ during the past two years) and then receive the same case with a rich defendant (a programmer with net monthly earnings of 80,380 and $82,600 \mathrm{CZK}) .{ }^{31}$ For comparison, gross average wage in the fourth quarter of 2012 (that is the quarter preceding the survey experiment) was $27,170 \mathrm{CZK}(\$ 1,380$ USD). Because the Czech Republic has a child tax credit, the net average wage for a childless person would be $20,776 \mathrm{CZK}$ ( $\$ 1,055 \mathrm{USD}) .^{32}$ The order is reversed for the other half of the subjects.

Upon providing the second answer, subjects are given the opportunity to correct their decisions, if they wish. This stage is described as an appellate court revision of the two cases, and these decisions are recorded separately. After their final decisions, respondents are debriefed about the motives behind their reasoning as well as their opinions on penal policy and potential policy changes. Finally, subjects are asked a series of questions about their background, demographic characteristics, and political attitudes.

${ }^{28}$ SOSCI SURVEY, https://www.soscisurvey.de (last visited Oct. 18, 2014).

${ }^{29}$ According to its home page, PHP.net "is a widely-used open source general-purpose scripting language that is especially suited for web development and can be embedded into HTML." What is PHP?, PHP, http://php.net/manual/en/intro-whatis.php (last visited Oct. 18, 2014).

${ }^{30}$ In United States' currency, the poor defendant earned approximately $\$ 625$ and $\$ 675$, respectively. According to the Czech National Bank's website, the exchange rate on April 11, 2013, during the time that we ran the experiment, was $19.7 \mathrm{CZK}$ to $\$ 1$ and $25.9 \mathrm{CZK}$ to one Euro. See XE Currency Table: CZK - Czech Koruna, XE (last updated Apr. 11, 2013, 16:00 UTC), http://www.xe.com/currency tables/?from=CZK\&date=2013-04-11.

31 Id. In United States' currency, the rich defendant earned approximately $\$ 4,080$ and $\$ 4,193$, respectively.

${ }^{32}$ Average Wages - 4th Quarter of 2012, CzECH STAT. OFF. (Mar. 11, 2013), http://www.czso.cz $/ \mathrm{csu} / \mathrm{csu} . n s f / e n g i n f o r m a c e / c p m z 031113$.doc. The equation used to reach the net average wage for a childless person is $20,776 \mathrm{CZK}$ (Net Wages) $=27,170 \mathrm{CZK}$ (Gross Wages) $-(1,766 \mathrm{CZK}+1,223$ CZK) (Social Insurance Payment + Health Insurance Payment) - (5,475 CZK - 0 CZK - 2,070 CZK) (Tax - Child Tax Credit multiplied by number of children - Standard Deduction). Each Additional child will lower the $5,475 \mathrm{CZK}$ number by $1,117 \mathrm{CZK}$. 
II. DATA

After thorough pre-tests, with the help of our colleagues and later a small group of students, we sent emails to approximately 400 first-year undergraduate students at the Faculty of Business and Economics, Mendel University in Brno and approximately 100 students at the University of Economics in Prague. ${ }^{33}$ In total, 215 students completed our survey between Friday, March 3, 2013 and Thursday, March 28, 2013. ${ }^{34}$

\section{A. Summary Statistics}

Table 1 reports the summary statistics of the collected dataset. The average fine in the first case is $370,000 \mathrm{CZK}(\$ 18,780)$ and in the second case it is 400,000 CZK $(\$ 20,300)$, however both medians are $240,000 \mathrm{CZK}(\$ 12,180)$. This suggests the two distributions are quite similar. An equal fine was assigned to both rich and poor criminals by forty-four percent of subjects; the rest varied the fine across their two cases. Distributions of prison sentences are also similar for the first and second cases. Average prison lengths are about 685 days, while both medians are 365 days. This suggests that a few people gave unusually high prison sentences. Close to ninety percent of subjects assigned the same prison terms in their two cases. The results are rather similar for the appellate stage in which subjects were offered the opportunity to review their two cases and revise their initial decisions.

The selected subjects' characteristics are at the bottom of Table 1. Our subjects were in their early twenties and both genders are represented equally. Their average political views are 3.6 on a 1-5 scale, showing that our subjects place themselves between the center and right wing, and on average their families' wealth is ranked as being in the middle of the wealth distribution in the society. Subjects took on average ten minutes to complete the survey.

${ }_{33}$ Professors sent the email and asked their students to participate in a ten-minute survey. It stressed the importance of their answers as well as giving assurance that the survey was anonymous. Because the emails were not sent by us and the survey was anonymous, we cannot report specific response rates for Brno and Prague.

${ }^{34}$ This includes only respondents who completed the whole questionnaire; forty-eight additional respondents finished before the end of the questionnaire. Reported results are based on data from complete questionnaires. However, the results do not change if all data was used, where applicable. Sex is missing for four respondents who completed the whole questionnaire, thus the number of observations for results that contain sex drops to 211 . 
Table 1. Summary Statistics

\begin{tabular}{lrrrrrrr}
\hline & Mean & St. Dev. & Min & Pctl(25) & Median & Pctl(75) & Max \\
\hline Initial decisions & & & & & & & \\
\cline { 1 - 5 } Fine in case 1 (CZK) & 370429 & 875355 & 0 & 100000 & 240000 & 300000 & 10000000 \\
Fine in case 2 & 400240 & 1445339 & 0 & 90000 & 240000 & 300000 & 20000000 \\
Equal fine to rich and poor (-1) & 0.44 & 0.50 & 0 & 0 & 0 & 1 & 1 \\
Prison in case 1. (days) & 682 & 814 & 0 & 180 & 365 & 858.0 & 5475 \\
Prison in case 2 & 689 & 814 & 0 & 180 & 365 & 1000 & 5475 \\
Equal prison to rich and poor & 0.87 & 0.33 & 0 & 1 & 1 & 1 & 1 \\
Appelate decisions & & & & & & & \\
\hline Fine in case 1 & 296622 & 488712 & 0 & 50000 & 240000 & 300000 & 5000000 \\
Fine in case 2 & 368122 & 1448837 & 0 & 49000 & 200000 & 300000 & 20000000 \\
Equal fine to rich and poor & 0.40 & 0.49 & 0 & 0 & 0 & 1 & 1 \\
Prison in case 1 & 679 & 813 & 0 & 120 & 365 & 1000 & 5475 \\
Prison in case 2 & 680 & 813 & 0 & 135 & 365 & 908.0 & 5475 \\
Equal prison to rich and poor & 0.87 & 0.34 & 0 & 1 & 1 & 1 & 1 \\
Age & 22 & 4.80 & 19 & 20 & 21 & 23 & 73 \\
Woman (=1) & 0.48 & 0.50 & 0 & 0 & 0 & 1 & 1 \\
Political views (1-5) & 3.60 & 1 & 1 & 3 & 4 & 4 & 5 \\
Wealth (decile) & 5.10 & 1.50 & 2 & 4 & 5 & 6 & 9 \\
Time to finish survey (seconds) & 590 & 166 & 212 & 468.0 & 581 & 705 & 1017 \\
\hline Number of observations & 215 & & & & & & \\
\hline
\end{tabular}

Wealth asks students to rank thetr families' wealth or income on 10 decile seale. Politics measures answers to a question about their political views in the realm of public finance and redistribution, it is coded as: 1 "Left", 2 "Leaning to left", 3 "Center", 4 "Leaning to right", and 5 -Right"

\section{B. Randomization Checks}

In order to check whether our experiment worked as intended, we ran a set of regressions testing whether the two scenarios and the order of defendants were assigned to our subjects randomly. To summarize, all coefficients on treatment dummies are close to zero and never statistically significant, meaning that subjects' observable characteristics do not differ across treatments. This indicates that the randomization indeed worked as intended. The randomization tests are described in more detail in the Appendix and results are reported in Table A1.

We later presented our first results to the students who took part in our survey. We discussed with them whether our assumptions and interpretations are appropriate. There was no disagreement on this. We also asked the students whether they had heard about the structure of our survey from their peers prior to responding, and none of them had. The most common reasons for not participating in the survey were the importance of other things to do and ignoring all requests to participate in online surveys. We find this comforting and an indication that our survey worked out as intended and that our identifying assumptions were not compromised. 


\section{RESULTS: RULES AND ATTITUDES}

\section{A. Within-Subject Results: The Rules}

Figure 1 plots our subjects' first and second decisions on prison terms and fines. The two plots on the left show the decisions of the subjects who first judged the poor defendant (the plumber) and then the rich defendant (the programmer). Looking at the top-left plot, it is apparent that most points lie on the 45-degree line, except for a few observations scattered around it. This pattern is also seen in the top-right plot, plotting decisions of subjects for which the order of defendants is reversed. Thus, the vast majority of subjects assigned the prison terms without explicit regard to the defendant's income. Specifically, over eighty-seven percent of our respondents gave the same prison term in both cases.
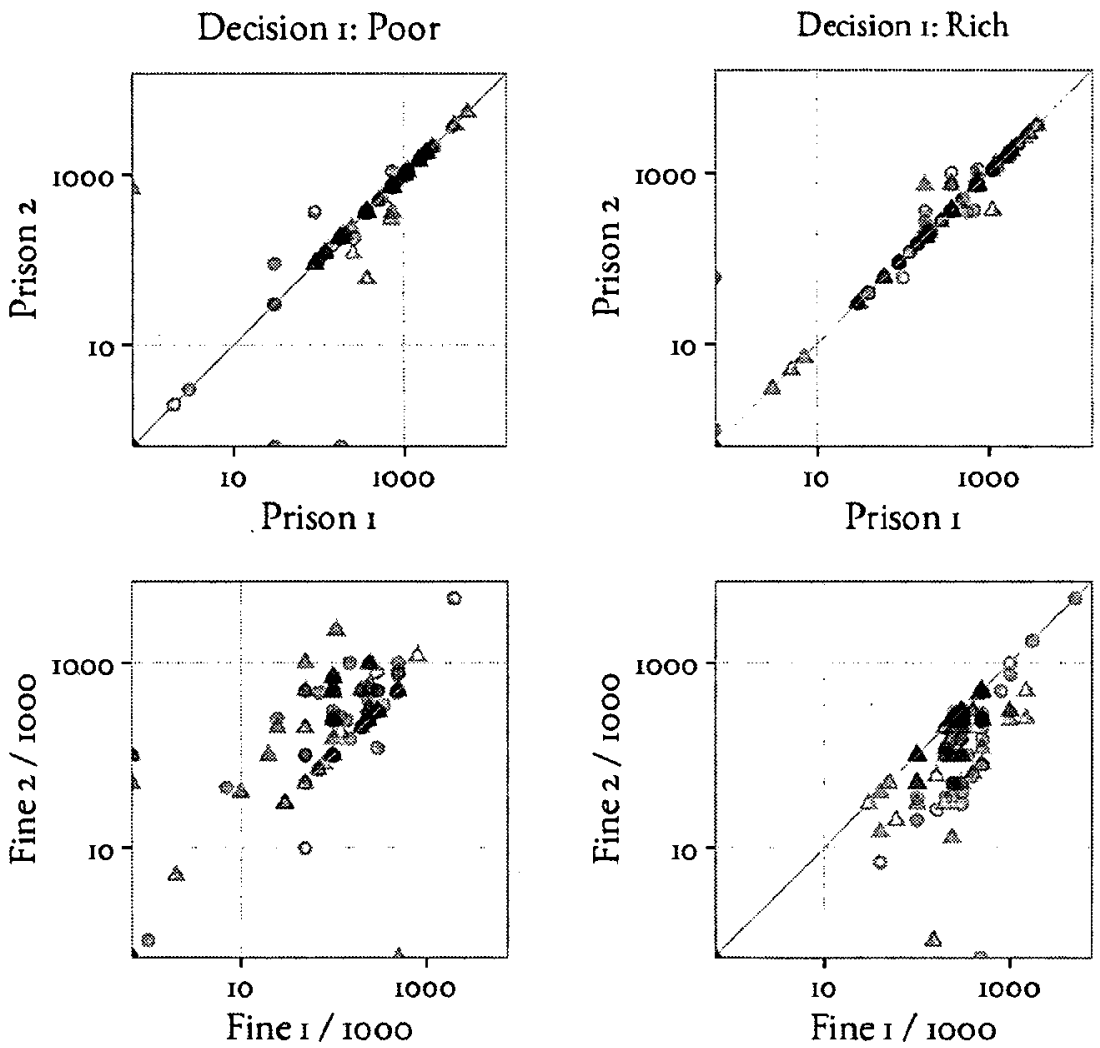

Scenario: Barbattery a Drunk driving

Figure 1. Within-subject variation in prison sentences and fines, by case order. Each point is a combination of a respondent's decisions in the first and the second cases in the sequence. Prison terms are measured in days; fines are in Czech Crowns divided by 1,000. 
The picture changes dramatically when we look at the two bottom plots showing decisions about fines. The majority of decision points in the bottom-left plot lie on the forty-five degree line or above it. These are cases where the first defendant was poor and the second rich. The interpretation is straightforward-our subjects assign an equal or higher fine to the rich defendant than to the poor. The bottomright plot of Figure 1 shows the decisions of subjects who decided the case with the rich defendant first. Most subjects in this group, again, vary the fine according to the defendant's income-the poorer defendant receives an equal or lower fine for the same offense than the rich defendant. The signal from the decisions plotted in Figure 1 is clear. A substantial portion of our subjects are applying a rule linking fine to income, whereby high-income offenders should receive higher fines and vice versa. When it comes to incarceration, however, the rule is very different: rich and poor should receive the same prison sentence for the same offense. ${ }^{35}$

\section{B. Between-Group Results: The Attitudes}

Our experimental design allows us to compare the rules, which are identified as implicit in within-subject decisions, with choices at the group level, which may capture unconscious tastes and attitudes that may not be consistent with those rules. This identification comes from the random assignment of first cases; one group received cases with poor defendants and the other group received cases with rich defendants. Because the first cases are decided without any reference to previous decisions, they may reflect unconscious attitudes, biases, or intuitions. For instance, people may be unconsciously biased against the rich and tend to give them heavier sentences. Or, they may tend to give heavier sentences to the poor, as they may not be able to pay the fine. Are group-level choices consistent with the rules? The answer is affirmative

This can be seen in Figure 2, which shows notched box plots of group-level data across our four treatments. Looking at fines first, they are higher for the rich defendant than the poor defendant both in the car accident scenario and in the fight scenario, however only the former difference in medians is statistically

${ }^{35}$ Note that fines and prison terms are decided simultaneously by the survey subjects, and therefore, this interpretation is valid. Our follow-up discussions with the respondents did not reveal any issues with our interpretation. 

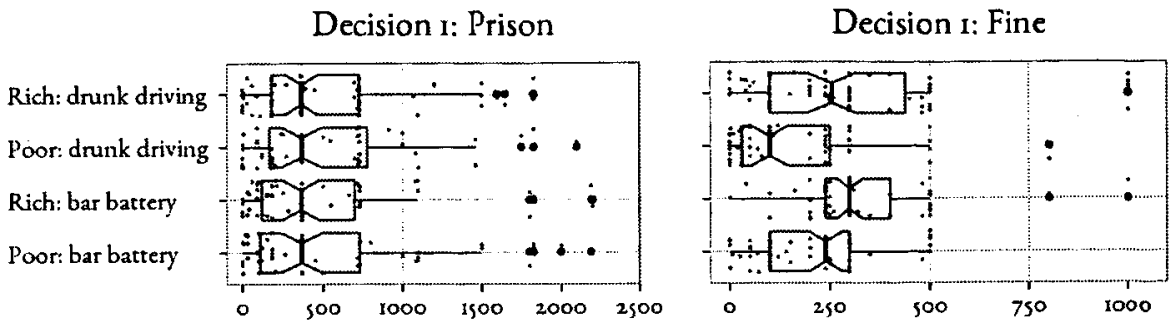

Decision 2: Prison

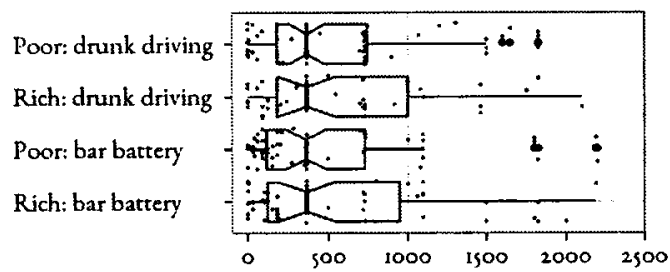

Decision 2: Fine

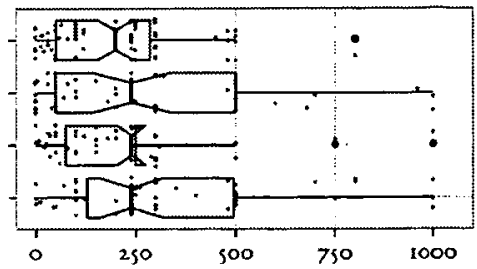

Figure 2. Between-group variation in prison sentences and fines, by case type and defendant's income. Prison terms are measured in days; fines are in Czech Crowns divided by 1000 . The upper and lower 'hinges' correspond to the 25 th and 75 th percentiles. The upper (lower) whisker extends from the hinge to the highest (lowest) value that is within $1.5 \times I Q R$ of the hinge, where $I Q R$ is the distance between the 25 th and 75 th percentiles. The notches extend $1.58 \times I Q R / \sqrt{n}$, where $n$ is the number of observations, roughly a 95 percent confidence interval for comparing medians. ${ }^{36}$

significant. ${ }^{37}$ This holds for first as well as second decisions in the sequence, except second decisions in the fight cases. Thus, intuitions seem to match the implicit rules in that, when it comes to fines, the rich should get a higher fine.

The picture is also consistent when we look at group-level decisions on prison terms. Rich and poor face similar median judgments, and this is true for first as well as second decisions. This finding strengthens our confidence that withinsubject variation identifies implicit rules to which people adhere. Moreover, we do not observe any systematic bias, such as an aversion towards the rich that would produce a deviation from that rule when there is no binding precedent.

\section{Debriefing}

After the respondents had made their decisions about punishment, we asked them a series of questions regarding the motives behind their decisions as well as direct questions about their opinion on the relevance of wealth and punishees' subjective suffering in punishment determination.

${ }^{36}$ See generally Robert McGill, John W. Tukey \& Wayne A. Larsen, Variations of Box Plots, 32 AM. STATISTICIAN 12 (1978) (describing variations of box plots).

${ }^{37}$ Non-overlapping notches suggest a statistically significant difference in medians at a five-percent level. See id. at 14. 
1. Motives and Purposes of Punishment.-To gain an insight into the motives that may have affected our subjects' decisions, we presented them with five possible purposes of punishment that represent standard theories of punishment: rehabilitation of the criminal; incapacitation, so that he is unable to commit further crimes; retribution or just deserts; specific deterrence of the criminal from future wrongdoing; and general deterrence of other potential criminals. ${ }^{38} \mathrm{We}$ then asked our respondents to evaluate (on a scale ranging from 0 to 10 ) the role of each purpose in their punishment decisions. ${ }^{39}$

We analyze the punishment motives in the following regression framework: let $Y$ be the value of a punishment purpose and $i$ an indicator of each respondent, we estimate

$$
Y_{i}=\beta_{0}+\beta_{1} C_{i}+\beta_{2} O_{i}+e_{i}
$$

where $C_{i}$ is a dummy variable equal to 1 if respondent $i$ received the car accident scenario and 0 if she received the bar fight scenario; $O_{i}$ is a dummy set to 1 if the respondent first received a case with the rich defendant and 0 for those who first received the poor defendant; finally, $e_{i}$ is the unexplained residual. The coefficient $\beta_{0}$ is the intercept estimating the mean of $Y_{i}$ for the group who received a sequence of two fight cases and had the poor defendant as their first case. Coefficients $\beta_{1}$ and $\beta_{2}$ are the parameters of interest, and they estimate the difference of mean $Y_{i}$, from the intercept, for the group who received the car accident scenario and for the group who received the rich defendant as their first case, respectively.

Table 2 reports the results of estimates of regression (1) with the scores of individual purposes as the outcomes. The group with the fight crime with a poor defendant in their first case is the reference category. While all five motives seem to play an important role in the fight scenario, specific deterrence appears to be the most important. All motives are weaker in the accident scenario, except the rehabilitation purpose. Notably, the intention to incapacitate is substantially smaller-the coefficient of -1.36 (on a 0 to 10 point scale with mean around 7.5 ) is substantively as well as statistically significant.

${ }^{38}$ See Kevin M. Carlsmith, The Roles of Retribution and Utility in Determining Punishment, $42 \mathrm{~J}$. EXPERIMENTAL SOC. PSYCHOL. 437, 437-38 (2006); Robert M. McFatter, Purposes of Punishment: Effects of Utilities of Criminal Sanctions on Perceived Appropriateness, $67 \mathrm{~J}$. APPLIED PSYCHOL. 255, 255 (1982).

${ }^{39}$ For example, the wording of the retributive purpose of the punishment in our survey is: "A deserved retaliation for the criminal act." 
Table 2. Purposes of Assigned Punishments

\begin{tabular}{lccccc}
\hline & & & & \multicolumn{2}{c}{ Deterrence } \\
\cline { 5 - 6 } & Rehabilitation & Incapacitation & Retribution & Specific & General \\
\hline Constant & $7.58^{* * *}$ & $7.30^{* * *}$ & $7.80^{* * *}$ & $9.27^{* * *}$ & $8.03^{* * *}$ \\
& $(0.36)$ & $(0.41)$ & $(0.37)$ & $(0.26)$ & $(0.32)$ \\
Car accident $(=1)$ & 0.34 & $-1.36^{* * *}$ & -0.41 & $-0.61^{* *}$ & -0.40 \\
& $(0.38)$ & $(0.45)$ & $(0.41)$ & $(0.29)$ & $(0.37)$ \\
Rich first (=1) & -0.14 & 0.20 & $0.96^{* *}$ & 0.22 & -0.05 \\
& $(0.38)$ & $(0.45)$ & $(0.42)$ & $(0.30)$ & $(0.37)$ \\
\hline Observations & 215 & 215 & 215 & 215 & 215 \\
$\mathrm{R}^{2}$ & 0.00 & 0.04 & 0.03 & 0.02 & 0.01 \\
\hline
\end{tabular}

Dependent variables are respondents' answers to five questions regarding the importance of five alternative purposes of punishments in their decisions. Respondents are asked to evaluate the relevance of each purpose on a scale ranging from 0 to 10. For instance, the wording of the general deterrence purpose is "To deter other potential criminals". Robust standard errors are in parentheses: ${ }^{*} p<0.1,{ }^{* *} p<0.05,{ }^{* * *} p<0.01$.

We suggest that the pattern of results in Table 2 is consistent with the qualitative difference between the two cases; our respondents seem to have different motives and see a different purpose to punishment for unintentional, albeit negligent behavior that led to an injury compared with a punishment for a deliberate attack against a physically weaker opponent. It is more feasible that the first will respond to incentives whereas the latter needs to be isolated from the society. Thus, we interpret these results as suggesting that our subjects understood their cases and that their decisions show a certain degree of consistency.

2. Respondents' Opinions on Subjective Aspects of Punishment.-To further gauge our understanding of respondents' decisions and general attitudes, we asked them a series of direct questions regarding the relevance of punishees' subjective perceptions and wealth in determining punishment. Specifically, we asked our subjects whether an offender's income or wealth should affect her fine or prison sentence and whether the fine or prison sentence should increase, decrease, or remain stable with higher income. The first four columns of Table 3 report the answers to these questions; the models are based on regression (1). Consistent with the patterns of decisions in Figures 1 and 2, the results for fines and imprisonment differ starkly. Our subjects lean toward the idea that fines should increase with wealth. However, they strongly disagree with the proposition that wealth should affect prison sentence length. The patterns of the results for the car accident and fight scenarios are virtually the same and do not differ for people who first punished the rich defendant compared with those who had to punish the poor defendant in their first case, as can be seen in the second and third row of coefficients in Table 3 . The only exception is that the individuals who received the rich criminal in their first case are more likely to agree that fines-but not prison terms-should be affected by the criminal's wealth. 
Table 3. Wealth, Punishment, and Technology

\begin{tabular}{|c|c|c|c|c|c|c|c|}
\hline & \multicolumn{4}{|c|}{ Punishment and Wealth } & \multicolumn{3}{|c|}{ Usefulness of fMRI } \\
\hline & $F(I) ?$ & $F^{\prime}(I)=?$ & $P(I) ?$ & $P^{\prime}(I)=?$ & $\begin{array}{l}\text { Should affect } \\
\text { punishment? }\end{array}$ & $F^{\prime}(I)>0 ?$ & $P^{\prime}(I)<0 ?$ \\
\hline Coding range: & {$[-2,2]$} & $\{-1,1\}$ & $\{-2,2\}$ & {$[-1,1\}$} & $\{-2,2\}$ & {$[-2,2\}$} & $\{-2,2\}$ \\
\hline Constant & $\begin{array}{l}0.25 \\
(0.19)\end{array}$ & $\begin{array}{l}0.59 * * * \\
(0.06)\end{array}$ & $\begin{array}{l}-1.61 * * * \\
(0.11)\end{array}$ & $\begin{array}{l}-0.02 \\
(0.03)\end{array}$ & $\begin{array}{l}-0.10 \\
(0.14)\end{array}$ & $\begin{array}{l}0.32^{*} \\
(0.19)\end{array}$ & $\begin{array}{l}-1.37^{* * *} \\
(0.13)\end{array}$ \\
\hline Car accident $(=1)$ & $\begin{array}{l}-0.08 \\
(0.21)\end{array}$ & $\begin{array}{l}-0.02 \\
(0.07)\end{array}$ & $\begin{array}{l}0.03 \\
(0.13)\end{array}$ & $\begin{array}{l}-0.03 \\
(0.03)\end{array}$ & $\begin{array}{l}-0.24 \\
(0.16)\end{array}$ & $\begin{array}{l}-0.13 \\
(0.20)\end{array}$ & $\begin{array}{l}-0.03 \\
(0.14)\end{array}$ \\
\hline Rich first $(=1)$ & $\begin{array}{l}0.37^{*} \\
(0.21)\end{array}$ & $\begin{array}{l}0.05 \\
(0.07) \\
\end{array}$ & $\begin{array}{l}-0.01 \\
(0.13) \\
\end{array}$ & $\begin{array}{l}0.01 \\
(0.03)\end{array}$ & $\begin{array}{c}0.01 \\
(0.16)\end{array}$ & $\begin{array}{l}0.17 \\
(0.20)\end{array}$ & $\begin{array}{l}0.00 \\
(0.15)\end{array}$ \\
\hline $\begin{array}{l}\text { Observations } \\
\mathbf{R}^{2}\end{array}$ & $\begin{array}{l}215 \\
0.02\end{array}$ & $\begin{array}{l}204 \\
0.00\end{array}$ & $\begin{array}{l}215 \\
0.00\end{array}$ & $\begin{array}{l}210 \\
0.01\end{array}$ & $\begin{array}{l}215 \\
0.01\end{array}$ & $\begin{array}{l}215 \\
0.00\end{array}$ & $\begin{array}{l}215 \\
0.00\end{array}$ \\
\hline
\end{tabular}

The outcome variables in first four columns are respondents' answers to questions whether fines $(F)$, of prison terms $(P)$ should depend on income and in what way $\left(F^{\prime}, P^{\prime}\right)$. The fifth column measures responses to a question whether technologies, such as fMRI. should be employed to tailor punishments to criminals. Columns six and seven measure answers to a question whether the rich should get higher fines if the technologies show that they perceive the fine as less "painful" than the poor and whether the rich should get lighter prison terms if technologies show that they experience incarceration more severely than the poor, respectively. Coding range $\{-2,2\}:-2$ "Strongly disagree", -1 "Disagree", 0 "Undecided", 1 "Agree", 2 "Strongly agree". Coding range $\{-1,1\} ;-1$-Should decrease", 0 "Should not change", 1 "Should increase", N/A "Do nor know" (dropped from regressions). Robust standard errors are in parentheses: ${ }^{*} p<0.1, * * p<0.05, * * * p<0.01$.

The last three columns of Table 3 report the respondents' answers to questions regarding the use of future technologies, such as functional magnetic resonance imaging, that allow criminals' subjective feelings or experience of punishment to be measured. Specifically, we first asked people whether information acquired by these means should play a role in the determination of punishment. Our subjects were rather unsure about this, as suggested by all three coefficients in the fifth column of Table 3. We then asked them whether rich people should receive higher fines if technologies systematically show that they perceive a certain fine less negatively than the poor. The result is a weak agreement. Finally, we asked our subjects whether rich people should receive lighter prison sentences if the technologies systematically report that they perceive incarceration more negatively than the poor-and they rather strongly disagreed.

In summary, these results are in line with our experimental findings. In addition, there is an indication that people may be averse to the idea that the subjective experience of punishment should determine its extent even if technologies were to make the required information available.

\section{WHAT EXPLAINS THE RULES?}

Although there is no disagreement on the equality of prison sentences, our subjects are split on the issue of whether the size of fine should depend on the offender's income, with between forty and forty-five percent assigning the same fine in both cases and fifty-five to sixty percent adjusting fine according to income. What explains the divide? We hypothesize that two factors may play a role, namely wealth and political views.

From a purely self-interested perspective, richer people should generally prefer fines set in nominal terms whereas poorer people should prefer fines to be 
proportional to income. ${ }^{40}$ At the same time, during discussions of our results we observed that a preference for the equal fine rule correlates with a preference for flat $\operatorname{tax}$ (a tax rate that does not progress with income). ${ }^{41}$ Such preferences may be driven by either the (expected) wealth of the respondent or her political preferences. This is because richer people would benefit from a flat-tax and poorer people would be hurt by it. ${ }^{42}$ At the same time, the progressive versus flat-tax perspective is a typical indicator of left-right divide on the political scale.

Because we asked our subjects about wealth as well as about their political views, our survey allows us to test these hypotheses. ${ }^{43}$ First, we ran a set of linear probability regressions, where the outcome is an indicator coded as 1 if the respondent assigned the same fine to the poor as to the rich offender and 0 otherwise. Specifically, we estimate

$$
Y_{i}=\beta_{0}+\beta_{1} P_{i}+\beta_{2} W_{i}+\beta_{3}^{\prime} X_{i}+e_{i}
$$

where $P_{i}$ is respondent is political orientation (coded from 1 to 5 on the left-right scale); $W_{i}$ is the wealth of her family; $X_{i}$ is a vector of socio-demographic characteristics and other control variables; and $e_{i}$ is the unexplained residual. The same regression is estimated for three alternative definitions of the outcome variable: (i) equal punishment in the first two original decisions (i.e. in the experimental phase); (ii) equal punishment in the appellate stage, where the respondents are presented both of their cases and asked to review their initial decisions; and (iii) equal punishment in their original two decisions and in their appellate decisions. ${ }^{44}$ The coefficients of interest are $\beta_{1}$ and $\beta_{2}$. These coefficients estimate the effect of political orientation and wealth, respectively, on the preference for equal punishment.

Table 4 reports the results. The estimates of the effect of political orientation on the probability that the respondent prefers the same fine for both rich and poor offenders is about 0.1 and is highly statistically significant across the three definitions of the outcome. The point estimate predicts that a person who describes her political views as "right" has about a forty percent higher probability of

40 This holds trues as long as the nominal fine is set so that it is higher than a proportional fine for poor people and the opposite holds true for the rich.

${ }^{41}$ Notice that this preference is not internally consistent, as the tax burden under a flat tax scheme is a function of income, whereas nominal fines are independent of income. A tax counterpart to the nominal fine would be a head tax.

${ }^{42}$ This conclusion assumes the flat rate would be between the lowest and the highest brackets of a progressive tax policy.

${ }^{43}$ Because our subjects are students and their income may be erratic, we asked about their family's wealth rather than their own. We believe that the family wealth captures the background of our subjects as well as their expected income level in the future. The exact wording of the question was: "If we ordered all families in the Czech Republic according to their wealth, in which category would your family fall?" They were offered a sliding scale with the extremes marked as "The lowest 10 percent" and "The highest 10 percent," respectively.

${ }^{44}$ Note that the third definition does not require the same punishment in all four decisions. 
preferring equal fines for the rich and the poor, compared to a person who describes her political preferences as "left. ${ }^{45}$ At the same time, wealth does not seem to influence the preference for the equal fine. All coefficient estimates in specifications (1) to (3) are essentially zero, although moderate positive or negative effects cannot be ruled out. Neither the respondents' sex nor their age appears to influence their preferences. The coefficient estimates on education level and field dummies are substantively large, however none is statistically significant.

Specifications (3) to (6) check the robustness of the effect of politics to case sequence and offense type the respondents received, and we also include the (log) of time the respondent spent on answering the survey. While respondents who received the case with the rich defendant as their first seem to be less likely to prefer an equal fine for both, the estimated effect is relatively small and not statistically significant. Neither the scenario nor the time spent on the survey seems to be related to the preference for equal fine. Looking at the effect of politics, it is remarkable that the coefficients are virtually the same as in specifications (1) to (3).

For comparison, Table 4 also reports results for preference about equal prison sentences. Interestingly, wealth of the respondent is estimated to have a negative impact on the preference for equal prison time. The estimated effects are however small and only marginally statistically significant so they should be interpreted with caution. None of the other sociodemographic variables are statistically significant and the estimates are small. Notably, the effect of political views is estimated to be zero. The estimate dummies for law and humanities students suggest that they are more likely to prefer equal punishment, compared to business students; however, the coefficients are not statistically significant. Similarly, the case sequence and crime type do not have any important effect on the preference for equal prison time for the rich and poor defendants, which is comforting. However, the time spent on the survey is positively related to the preference for equal prison term, and the effect is substantively large and statistically significant. This suggests that some of the few respondents who did vary the prison term across their cases may have paid less attention while answering the survey.

In summary, the results in Table 4 suggest that political views are strongly related to the preference for nominal versus proportional fine, while respondents' wealth is unrelated to it. At the same time, the preference for equal prison time for rich and poor offenders is independent of politics. But which parts of the political scale drive the effect of politics on preferences about fines?

${ }^{45}$ That is moving on the 1 to 5 scale by 4 units times the coefficient estimate 0.1 . 


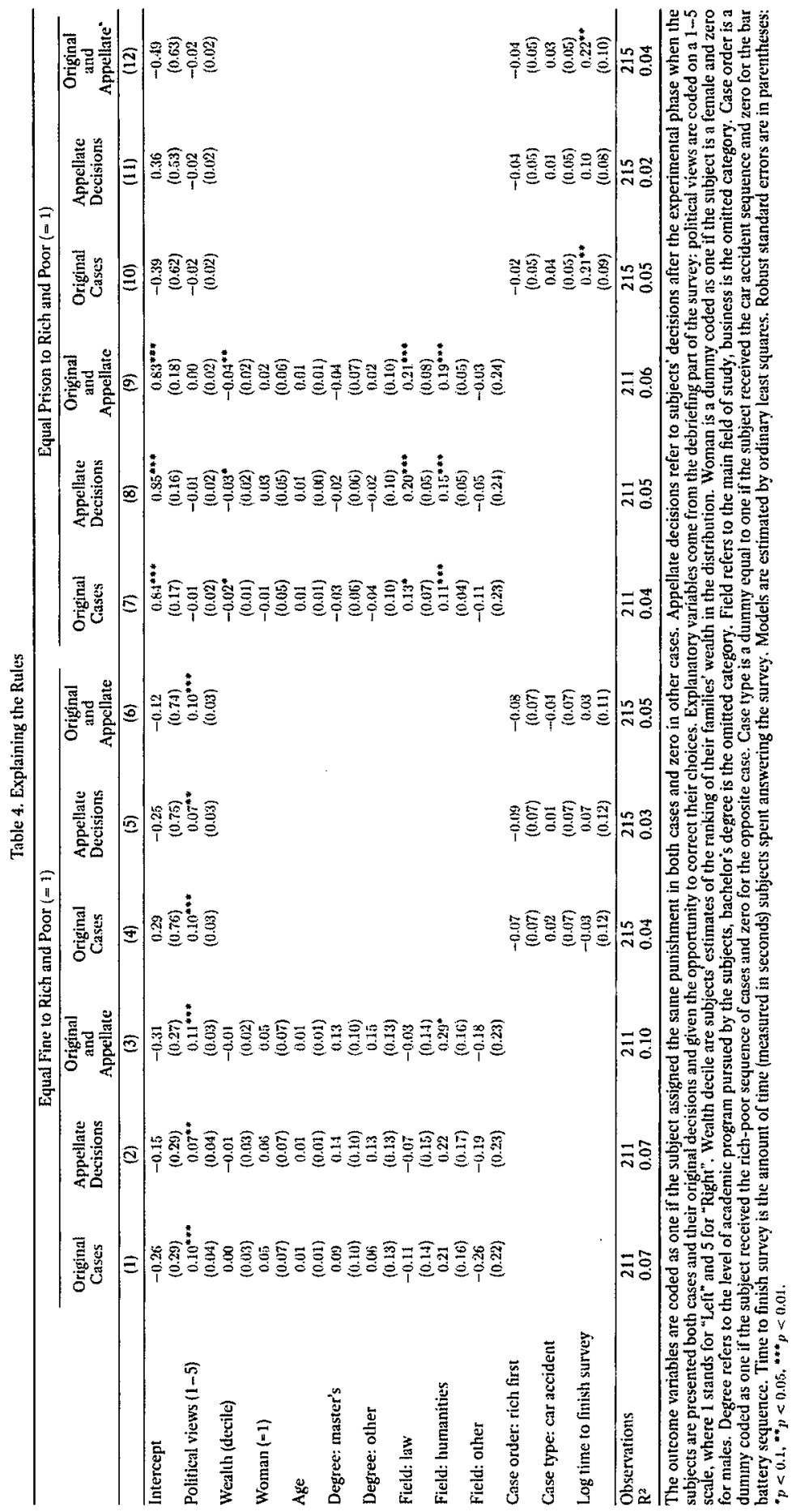




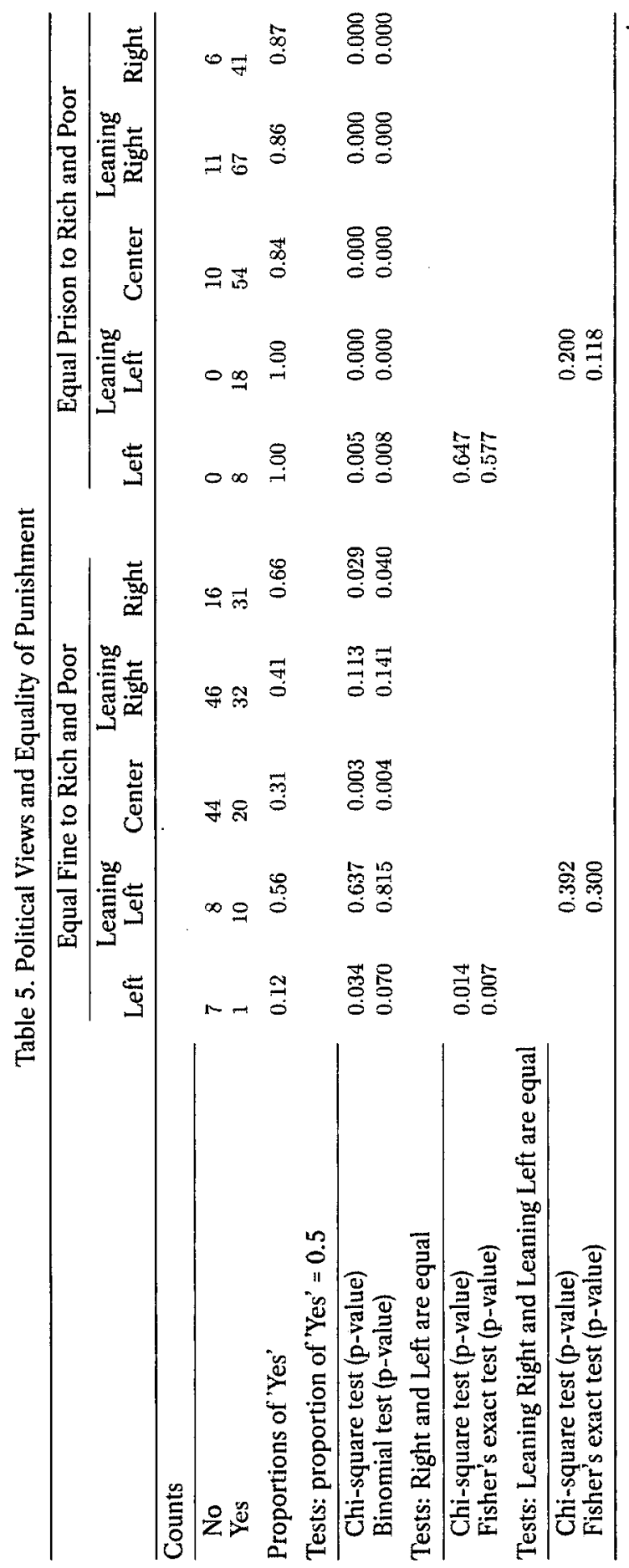


Table 5 aims at gaining a more detailed insight into the role of politics in explaining our findings. It cross-tabulates political views and preferences about the equality of fines and prison sentences, and it reports a set of statistical tests of the observed patterns. For respondents who describe their political views as "leaning" either left or right, the hypothesis that the number of people who prefer an equal fine is the same as the number of those who prefer an income-contingent fine cannot be rejected. However, when we look at people who describe their views as right or left, the equality of populations is rejected at the 0.05 level of significance by three out of four tests and by all four tests at the 0.1 level. Thus, the effect of politics on preference about equality of fines is driven by the extremes. This is supported by testing whether the proportions among those in the left category are the same as the proportions of subjects among the right: both of the reported tests comfortably reject that hypothesis. At the same time, the tests fail to reject that leaning left respondents have the same preferences on equality of fines as those who are leaning right.

The same exercise was performed for preferences about equal prison sentences, and the results are reported in the right part of Table 5 . They are very different from those for fines. All tests strongly reject that the number of people who prefer equal prison time for the rich and the poor is the same as the number of those who do not. At the same time, the hypothesis that the preferences of the left are the same to those of the right cannot be rejected.

In short, the results reported in this section suggest that there is a disagreement between left-wing and right-wing respondents as to whether fines should be income-contingent or fixed nominally. Our results also suggest that there is a common preference that punishment should not depend on an offender's income. This holds for the left, right, and center, and for the relatively poor, as well as the relatively rich.

\section{CONCLUSION}

There is little doubt that subjective factors affect the experience of punishment. Although offenders' punishments are, from a formal point of view, the same, they are punished with different severity. One of the important factors that affects the subjective experience of punishment is the wealth of the offender. Therefore, policy proposals that paid more attention to those subjective factors might result in variations in punishment that is systematically related to wealth and income. Using an experimental approach, we have studied people's preferences with respect to punishment and income, focusing on the two most common types of punishment: incarceration and fines. Our findings suggest that subjective factors may-and perhaps should-affect the determination of fines. However, things are different in the case of incarceration, where such a possibility is strongly rejected across the political spectrum as well as income categories. Neither do we find any systematic 
group-level biases that would suggest people want (perhaps subconsciously) to punish the rich and the poor differently. ${ }^{46}$

The subjectivism vs. objectivism controversy in the philosophy of criminal law is the dispute between global subjectivism ("all punishment should be subjective") and global objectivism ("all punishment should be objective"). However, there is a forgotten (but open) middle ground between the Scylla of global subjectivism and the Charybdis of global objectivism. ${ }^{47}$ Indeed, it is possible to interpret our findings as representing a challenge for both globalisms. Our findings demonstrate that people's intuitions about appropriate punishment are not general but vary across types of punishment. The respondents often preferred the subjective conception in the case of a monetary punishment; however, the overwhelming majority preferred the objective conception in the case of incarceration. Of course, the public's intuitions are, in principle, fallible, but they are a good reason to take the punishment-specific conception seriously.

We suggest that there is no need for legislators to choose a particular, "one size fits all" theory of punishment. Perhaps the main question should rather be: what conception (subjective or objective, or a mix) of punishment is more appropriate for a particular type of punishment? The subjectivism versus objectivism debate has been predominantly concerned with punishment by incarceration. Our results suggest that shifting focus to other types of punishment may be in place. We see more opportunities for public discussion and experimentation with subjectivist policy reforms in the realm of monetary punishment. Our findings suggest that unlike for incarceration - the question about a more appropriate conception for the monetary punishment seems to be an open issue.

${ }^{46}$ Note that this finding is generally consistent and complements previous findings by Theodore Eisenberg et al. See Eisenberg et al., supra note 13, at 751, 758, 763, 771-72.

${ }^{47}$ Scylla and Charybdis were mythical sea monsters depicted in Homer's Odyssey: "Then we entered the Straits in great fear of mind, for on the one hand was Scylla, and on the other dread Charybdis ..." They represent a hard choice between two evils. See HOMER, THE ODYSSEY 101 (Samuel Butler trans., Plain Label Books 2009). 


\section{APPENDIX}

\section{A. Randomization Checks}

Let $Y$ be a demographic characteristic and $i$ an indicator of each respondent, we estimate

$$
Y_{i}=\beta_{0}+\beta_{1} C_{i}+\beta_{2} O_{i}+e_{i}
$$

where $C_{i}$ is a dummy variable equal to 1 if respondent $i$ received the car accident scenario and 0 if she received the bar fight scenario; $O_{i}$ is a dummy set to 1 if the respondent first received a case with the rich defendant, and it is 0 for those who first received the poor defendant; finally, $e_{i}$ is the unexplained residual. $\beta_{0}$ is the intercept estimating the mean of $Y_{i}$ for the group who received a sequence of two fight cases and had the poor defendant as their first case. $\beta_{1}$ and $\beta_{2}$ are the coefficients of interest, and they estimate the difference of mean $Y_{i}$, from the intercept, for the group who received the car accident scenario and for the group who received the rich defendant as their first case, respectively.

The regression thus tests whether the other groups differ. If the randomization worked as intended, the coefficients $\beta_{1}$ and $\beta_{2}$ should be close to zero. We estimate regression (1) for seven alternative characteristics of our subjects from the demographic section of our survey. Results are reported in Table A1.

Table A1. Sample and Randomization

\begin{tabular}{lccccccc}
\hline & Sex & Age & Student & Bachelor & Business & Wealth & Politics \\
\hline Constant & $0.48^{* * *}$ & $22.06^{* * *}$ & $0.97^{* * *}$ & $0.60^{* * *}$ & $0.82^{* * *}$ & $1.93^{* * *}$ & $3.07^{* * *}$ \\
& $(0.06)$ & $(0.5)$ & $(0.02)$ & $(0.06)$ & $(0.05)$ & $(0.19)$ & $(0.13)$ \\
Car accident $(=1)$ & 0.05 & -0.0 & -0.01 & -0.02 & 0.04 & 0.12 & -0.08 \\
& $(0.07)$ & $(0.6)$ & $(0.02)$ & $(0.07)$ & $(0.05)$ & $(0.21)$ & $(0.14)$ \\
Rich first $(=1)$ & -0.03 & 0.2 & -0.00 & 0.07 & -0.01 & 0.20 & 0.03 \\
& $(0.07)$ & $(0.67)$ & $(0.02)$ & $(0.07)$ & $(0.05)$ & $(0.21)$ & $(0.14)$ \\
\hline Observations & 211 & 215 & 215 & 215 & 215 & 215 & 215 \\
$\mathrm{R}^{2}$ & 0.00 & 0.00 & 0.00 & 0.01 & 0.00 & 0.01 & 0.00
\end{tabular}

Variable definitions: Sex is coded as 0 for men and 1 for wonen (Cour observations are missing). Student is coded as 1 if the respondent is a student and 0 otherwise. Bachelor is coded as 1 if the respondent pursues a bachelor degree and 0 otherwise, Business is coded as one if the respondent's major is in Business or Economics and 0 otherwise. Wealth asks students to rank their families' wealth or income on 10 decile scale. Politics measures answers to a question about their political views in the realm of public finance and redistribution, it is coded as: 1 "Left", 2 "Leaning to heft", 3 "Center", 4 "Leaning to right", and 5 "Right". Standard errors are in parentheses: ${ }^{*} p<0.1, * * p<0,0,{ }^{* * *} p<0.01$. 


\section{B. Instructions and the Scenarios}

\section{INTRODUCTION}

We are interested in people's attitudes toward pecuniary and prison punishments. You will be presented with two criminal cases and asked to decide on a punishment in each of them. You are completely free to select the sentence you see appropriate, in other words, no particular jurisdiction applies. The only requirement is that you decide one case at a time, only after deciding a case move to the next one - as a real judge would. You can return to decided cases, however you cannot revise your decisions. After you make your choices, we ask you a few more questions about your decisions and about you. This form is anonymous, please do not state your name anywhere on it. 


\section{The Car Accident Scenario - Rich Defendant in the First Case}

\section{CASE 1}

Facts: On February 2, 2012, the convicted defendant, a forty-year-old programmer, drove home from his friend's bachelor party and collided with another car at approximately 9:35 p.m. after passing a red light, injuring a twenty-nineyear-old mother of two children. He had 0.26 percent alcohol content in his blood at the time of the accident.

The victim suffered brain trauma, a broken hipbone, and psychic shock, putting her out of work for four months. Six months of additional physical therapy was necessary in order to fully heal her injury. An expert established the total damages (consisting of medical expenses, forgone earnings, compensation for pain and suffering, and car repair costs) to be $240,000 \mathrm{CZK}$.

The defendant's insurance company paid damages. However, because of the involvement of alcohol, the defendant is obliged to fully compensate the insurance company. The defendant's monthly after-tax income in the last two years was 80,380 and $82,600 \mathrm{CZK}$. He has no prior criminal record.

Task: Suppose you are a judge who must decide on a punishment, a combination of a prison term and a fine, for the convicted defendant. No particular jurisdiction applies; the sentence is entirely your decision.

\section{Your Decision}
Fine:
Czech Crowns.

Prison term:

days. 
CASE 2

Facts: On February 2, 2012, the convicted defendant, a forty-year-old plumber, drove home from his friend's bachelor party and collided with another car at approximately 9:35 p.m. after passing a red light, injuring a twenty-nine-yearold mother of two children. He had 0.26 percent alcohol content in his blood at the time of the accident.

The victim suffered brain trauma, a broken hipbone, and psychic shock, putting her out of work for four months. Six months of additional physical therapy was necessary in order to fully heal her injury. An expert established the total damages (consisting of medical expenses, forgone earnings, compensation for pain and suffering, and car repair costs) to be $240,000 \mathrm{CZK}$.

The defendant's insurance company paid damages. However, because of the involvement of alcohol, the defendant is obliged to fully compensate the insurance company. The defendant's monthly after-tax income in the last two years was 12,270 and 13,330 CZK. He has no prior criminal record.

Task: Suppose you are a judge who must decide on a punishment, a combination of a prison term and a fine, for the convicted defendant. No particular jurisdiction applies; the sentence is entirely your decision.

\section{Your Decision}

Fine:

Czech Crowns.

Prison term: days. 
2. The Bar Fight Scenario - Poor Defendant in the First Case

\section{CASE 1}

Facts: On February 2, 2012, the convicted defendant, a twenty-nine-year-old plumber, had a squabble with another person in a bar and later assaulted him. The injured person, compared to the assailant, was of smaller stature and has suffered mild to serious injuries as a result of the assault.

Specifically, the injuries included serious brain trauma, multiple cheekbone fractures (surgical intervention was necessary), and a kidney contusion. He was hospitalized for fourteen days and was subsequently out of work for three and a half months.

A court expert established the total damages (consisting of medical expenses, forgone earnings, and compensation for pain and suffering) to be $240,000 \mathrm{CZK}$. The defendant must pay these damages to the injured person.

The defendant's monthly after-tax income in the last two years was 12,270 and 13,330 CZK. Three years earlier, he was convicted after causing a car accident while intoxicated, causing a serious injury. He was sentenced to a monetary sanction and a six-month prison sentence conditionally suspended for one year.

Task: Suppose you are a judge who must decide on a punishment, a combination of a prison term and a fine, for the convicted defendant. No particular jurisdiction applies; the sentence is entirely your decision.

\section{Your Decision}

Fine: $\quad$ Czech Crowns.

Prison term: days. 


\section{CASE 2}

Facts: On February 2, 2012, the convicted defendant, a twenty-nine-year-old programmer, had a squabble with another person in a bar and later assaulted him. The injured person, compared to the assailant, was of smaller stature and has suffered mild to serious injuries as a result of the assault.

Specifically, the injuries included a serious brain trauma, multiple cheekbone fractures (surgical intervention was necessary), and a kidney contusion. He was hospitalized for fourteen days and was subsequently out of work for three and a half months.

A court expert established the total damages (consisting of medical expenses, forgone earnings, and compensation for pain and suffering) to be $240,000 \mathrm{CZK}$. The defendant must pay these damages to the injured person.

The defendant's monthly after-tax income in the last two years was 80,380 and $82,600 \mathrm{CZK}$. Three years earlier, he was convicted after causing a car accident while intoxicated, causing a serious injury. He was sentenced to a monetary sanction and a six-month prison sentence conditionally suspended for one year.

Task: Suppose you are a judge who must decide on a punishment, a combination of a prison term and a fine, for the convicted defendant. No particular jurisdiction applies; the sentence is entirely your decision.

\section{Your Decision}

Fine: $\quad$ Czech Crowns.

Prison term: days. 


\section{APPEAL}

Now, you can revise your previous decisions. Suppose you are a judge of a court of the second instance dealing with an appeal. Avoid utilizing the reformatio in peius principle (amending the lower decision in a negative manner or choosing a harsher punishment). This means that, you can alter each decision without limitation or uphold it. Both first-instance decisions are at your disposal.

Subjects are now presented both cases in full description simultaneously. The cases include their earlier decisions on punishment. Below each case are prompts, in which they are requested to state their "second stage" decisions on punishments. 


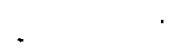

